JURNAL KETAHANAN NASIONAL

ISSN: 0853-9340 (Print), ISSN: 2527-9688 (Online)

Online sejak 28 Desember 2015 di: http://jurnal.ugm.ac.id/JKN

VOLUME 23

No. 1, 27 April 2017

Halaman 37-48

\title{
Peran Karang Taruna Dalam Pemberdayaan Penyandang Disabilitas Di Desa Karangpatihan, Kabupaten Ponorogo Dan Implikasinya Terhadap Ketahanan Ekonomi Keluarga
}

\author{
Citra Gaffara Taqwarahmah \\ Karang Taruna Kertosari \\ Email: citragaffara24@gmail.com \\ Bagus Riyono \\ Fakultas Psikologi Universitas Gadjah Mada Yogyakarta \\ Email: bagus@ugm.ac.id \\ Diana Setiyawati \\ Fakultas Psikologi Universitas Gadjah Mada Yogyakarta \\ Email: diana_psy@ugm.ac.id
}

\begin{abstract}
This study aimed to analyzed the role of youth in the empowerment of persons with disabilities and to analyzed the implications for families economic resilience of persons with disabilities.

This research was a qualitative descriptive study with data collection throught: (1) interview, (2) observation, and (3) the documentation with investigation techniques using triangulation techniques.

The results of this study indicated Youth had a role in encouraging the participation of all elements of society to petrified with disabilities achieved prosperity. Empowerment activities also had contributed to the increase in income persons with disabilities. Although there was an increase in income, family economic resilience, conditions of persons with disabilities was still at the poverty line
\end{abstract}

Keywords: Role Of Youth, Empowerment of Persons With Disabilities, Family Economic Resilience

\begin{abstract}
ABSTRAK
Penelitian ini bertujuan untuk menganalisis peran karang taruna dalam pemberdayaan penyandang disabilitas dan menganalisis implikasinya terhadap ketahanan ekonomi keluarga penyandang disabilitas.

Penelitian ini merupakan penelitian deskriptif kualitatif dengan teknik pengumpulan data melalui: (1) wawancara, (2) observasi, dan (3) dokumentasi dengan teknik pemeriksaan menggunakan teknik triangulasi.

Hasil penelitian ini menunjukkan Karang Taruna memiliki peran dalam mendorong partisipasi seluruh elemen masyarakat untuk membantu penyandang disabilitas mencapai kesejahteraan. Kegiatan pemberdayaan juga telah memberi kontribusi pada peningkatan pendapatan penyandang disabilitas. Meski terdapat peningkatan pendapatan, kondisi ketahanan ekonomi keluarga penyandang disabilitas masih berada pada garis kemiskinan
\end{abstract}

Kata Kunci : Peran Karang Taruna, Pemberdayaan Penyandang Disabilitas, Ketahanan Ekonomi Keluarga. 


\section{PENGANTAR}

Ketahanan nasional adalah sebuah konsepsi pertahanan yang bersifat semesta, serta bertujuan untuk kelangsungan hidup bangsa dan negara Indonesia yang merdeka dan berdaulat yang berdasarkan pada kekuatan diri sendiri (Departeman Pertahanan RI, 2008). Salah satu yang menjadi gatra dalam ketahanan nasional adalah ketahanan ekonomi, di mana perekonomian merupakan selah satu tolok ukur dari kemajuan sebuah bangsa. Untuk dapat mewujudkan ketahanan ekonomi diperlukan dukungan dalam bentuk sistem perekonomian yang kuat dan bertumpu pada ketahanan dan kemampuan bangsa sendiri, baik dalam hal sumber daya alam maupun sumber daya manusia yang berkualitas, sehingga tidak mudah goyah.

Laju pertumbuhan ekonmi suatu negara ditopang oleh perekonomian suatu daerah, adapun unit terkecil perekonomian daerah ditentukan oleh keluarga sebagai basis dari ketahanan ekonomi, sehingga perekonomian dari sebuah keluarga merupakan syarat utama dari berkembangnya ketahanan ekonomi. Produktivitas ekonomi harus sesuai dengan potensi yang ada di dalam masyarakat sehingga arah kebijakan yang akan dibuat mampu melihat realitas yang ada di dalam masyarakat (Yusuf, 2016). Komponen petumbuhan ekonomi tidak dapat dilepaskan dari komponen pembagian pendapatan. Pertumbuhan ekonomi tanpa terjadinya proses pembagian pendapatan atau sebaliknya pembagian pendapatan tanpa pertumbuhan ekonomi merupakan sesuatu yang timpang (Oktavianti, 2014)

Dewasa ini Indonesia masih dihadapkan pada posisi di mana masih besarnya tingkat kemiskinan terutama di daerah pedesaan. Permasalahan kemiskinan dan rendahnya pendapatan merupakan masalah utama dalam pembangunan ekonomi, dengan demikian peran serta masyarakat dalam mendorong pembangunan di bidang ekonomi sangat diperlukan. Menurut Sumaryadi (2005) salah satu cara untuk mengatasi kemiskinan yang terjadi adalah dengan menggunakan pendekatan partisipasif di mana pembangunan ini berasal dari masyarakat, diselengarakan secara mandiri oleh masyarakat dan hasilnya dinikmati oeleh seluruh masyarakat. Pembangunan partisipatif erat kaitanya dengan pemberdayaan masyarakat, di mana pada pembangunan partisipatif diperlukan upaya atau langkah untuk mempersiapakan masyarakat guna memperkuat kelembagaan masyarakat agar mereka mewujudkan kemajuan, kemandirian dan kesejahteraan dalam suasana keadilan yang berkelanjutan untuk meningkatkan harkat dan martabat serta mampu melepaskan dari perangkap kemiskinan dan keterbelakangan.

Salah satu komponen masyarakat yang memiliki hambatan dalam melepaskan diri dari belenggu kemiskinan adalah penyandang disabilitas. Bertumpu pada Pasal 17 UU No. 8 Tahun 2016 tentang Penyandang Disabilitas memberikan aturan mengenai hak kesejahteraan sosial bagi penyandang disabilitas yang meliputi hak rehabilitasi sosial, jaminan sosial, pemberdayaan sosial, dan perlindungan sosial. Desa Karangpatihan merupakan sebuah desa yang terletak di Kabupaten Ponorogo yang terkenal dengan julukan kampung idiot. Menurut data sensus desa, jumlah penyandang disabilitas di desa tersebut mencapai 89 jiwa yang menyebar di seluruh desa. Keberadaan penyandang disabilitas yang cukup banyak di Desa Karangpatihan menjadikan ekonomi di desa tersebut tidak dapat dibanggakan. 
Citra Gaffara Taqwarahmah, Bagus Riyono, Diana Setiyawati -- Peran Karang Taruna Dalam Pemberdayaan Penyandang Disabilitas Di Desa Karangpatihan, Kabupaten Ponorogo Dan Implikasinya Terhadap Ketahanan

Ekonomi Keluarga

Keterbatasan yang dimiliki penyandang disabilitas di Desa Karangpatihan memaksanya mengandalkan bantuan orang lain untuk bertahan hidup. Menyadari hal tersebut memicu kesadaran dari para pemuda Desa Karangpatihan untuk menciptakan sebuah kegiatan ekonomi yang digunakan untuk membantu kemandirian penyandang disabilitas. Pemuda merupakan bagian yang tidak dapat dipisahkan dari perubahan suatu bangsa. Dapat dikatakan bahwa prestasi pemuda adalah prestasi bangsa, para generasi mudalah yang nantinya memegang tongkat estafet kepemimpinan bangsa. Untuk itu perlu sumber daya manusia yang unggul, tangguh dan ulet serta mempunyai karakter yang baik. Jika pemuda bangsa mengalami kemunduran, hal tersebut ikut berdampak buruk pada kondisi bangsa. Oleh sebab itu, pemuda menjadi unsur yang penting dalam perkembangan bangsa dan negara (Shofa, 2016).

Ide pembuatan kegiatan pemberdayaan oleh Karang Taruna Desa Karangpatihan diharapkan mejadi alternatif bagi peningkatan penghasilan yang selanjutnya memiliki implikasi terhadap ketahanan ekonomi keluarga penyandang disabilitas. Untuk itu penelitian ini bertujuan mengetahui kontribusi karang taruna sebagai organisasi yang berperan dalam pemberdayaan penyandang disabilitas di Desa Karangpatihan dan menganalisis implikasi dari peran Karang Taruna dalam pemberdayaan penyandang disabilitas Dusun Tanggungrejo terhadap ketahanan ekonomi keluarga.

Penelitian terkait dengan penyandang disabilitas di Desa Karangpatihan telah banyak dilakukan sebelumnya, namun penelitian mengenai peran pemuda dalam pemberdayaan penyandang disabilitas dan implikasinya terhadap ketahanan ekonomi keluarga belum pernah diteliti. Seperti pada penelitian yang ditulis oleh Huda (2015) dengan judul Kepemimpinan Kepala Desa Dalam Meningkatkan Sumber Daya Manusia Desa Karangpatihan (Studi Kasus Pada Masyarakat Miskin dan Penderita Retradasi Mental di Desa Karangpatihan, Kecamatan Balong Kabupaten Ponorogo), memberikan penekanan pada kemampuan seorang pemimpin dalam hal ini adalah Kepala Desa Karangpatihan dalam meningkatkan kualitas sumber daya manusia di Desa Karangpatihan.

Pada penelitian lain juga telah membahas terkait dengan penyandang disabilitas di Desa Karangpatihan oleh Kementrian Kesehatan RI menekankan pada pendalaman pola budaya pemenuhan pangan gizi dalam upaya pertumbuhan kesehatan anak balita di Desa Karangpatihan. Dari hasil penelitian diperoleh bahwa gangguan pertumbuhan kesehatan masyarakat yang berupa idiot dan cacat fisik masih banyak ditemukan pada golongan dewasa dan anak. Potensi dari sumber pangan pada musim kemarau cukup sulit, terkendala dengan faktor irigasi yang memang daerah ini merupakan daerah yang sulit air maka (Badan Penelitian dan Pengembangan Kesehatan Kementerian Kesehatan RI, 2011).

Adapun penelitian ini menggunakan lima teori yang untuk mengarahkan peneliti meliputi: Pertama, teori peran, dimaksud dengan peran adalah segala tindakan yang dilakukan oleh seseorang atau lembaga yang mempunyai kedudukan tertentu dalam masyarakat dalam melaksanakan hak dan kewajiban yang dimilikinya sesuai dengan kedudukan dan fungsinya (Zulkarnain, 2015). Kedua, Karang Taruna, pengertian Karang Taruna dijelaskan dalam Peraturan Menteri Sosial No. 77/HUK/2010 Pasal 1 ayat (1) 
yaitu "Karang Taruna adalah organisasi sosial kemasyarakatan sebagai wadah dan sarana pengembangan setiap anggota masyarakat yang tumbuh dan berkembang atas dasar kesadaran dan tanggung jawab sosial dari, oleh dan untuk masyarakat terutama generasi muda di wilayah desa/ kelurahan terutama bergerak di bidang usaha kesejahteraan sosial". Ketiga, penyandang disabilitas, menurut WHO, disabilitas adalah suatu ketidakmampuan melakukan suatu aktivitas/ kegiatan tertentu sebagaimana layaknya orang normal yang disebabkan oleh kondisi hilangnya atau ketidakmampuan baik psikologis, maupun kelainan struktur anatomi (www.kemenpppa.go.id diakses pada tanggal 4 April 2016). Keempat, pemberdayaan, menurut Sutoso (2002) pemberdayaan merupakan suatu proses mengembangkan, memandirikan, menswadayakan, memperkuat posisi tawar menawar masyarakat lapisan bawah terhadap kekuatan-kekuatan penekan di segala bidang dan sektor kehidupan. Kelima adalah ketahanan ekonomi keluarga, ketahanan ekonomi keluarga merupakan kondisi dinamika suatu keluarga yang berisi keuletan dan ketangguhan yang mengandung kemampuan mengembangkan kekuatan keluarga dalam menghadapi dan mengatasi segala tantangan, ancaman, hambatan serta gangguan yang datang dari luar maupun dari dalam yang langsung maupun tidak langsung membahayakan kelangsungan kehidupan ekonomi keluarga.

Penelitian ini merupakan penelitian deskriptif kualitatif. Penelitian ini mengambil lokasi penelitian di Desa Karangpatihan, Kecamatan Babadan, Kabupaten Ponorogo, Provinsi Jawa Timur dengan menfokuskan penyandang disabilitas yang ada di Dusun Tanggungrejo. Adapun metode pengumpulan data menggunakan teknik (1) wawancara mendalam (in depth interview) yang dilakukan dengan menggunakan pedoman wawancara (interview guide) Pengambilan informan dilakukan berdasarkan pada pengelompokan infoman utama dan informan pendukung yang dipilih berdasarkan kedekatan pada objek penelitian. (2) Observasi yang dilakukan langsung ke Desa Karangpatihan, Kabupaten Ponorogo sehingga memperoleh gambaran langsung kondisi tempat penelitian dan interaksi yang berlangsung antara subjek dan objek pemberdayaan. (3) Dokumentasi dilakukan melalui dokumen pada kantor desa, rumah kepala desa, Pusat Pelatihan Kerja dan dokumen-dokumen yang terkait yang mendukung penelitian. (4) Internet.

Untuk menentukan keabsahan data penelitian menggunakan teknik triangulasi di mana kebenaran dari data dilakukan dengan cek silang antar data dengan membandingkan data yang terkumpul dengan hasil observasi, pengumpulan dokumentasi dan wawancara dengan informan sehingga jawaban penelitian dapat disimpulkan.

\section{PEMBAHASAN}

Indonesia merupakan negara yang turut aktif dalam menjamin penegakan HAM bagi penyandang disabilitas. Salah satu yang terlihat dari kesungguhan pemerintah adalah perubahan Undang-undang yang lebih berparadigma untuk memenuhi hak penyandang disabilitas. Merujuk pada Pasal 1 poin 1 dalam Undang-undang No. 8 Tahun 2016, memberi pengertian baru terkait penyandang disabilitas yaitu : "Penyandang disabilitas adalah setiap orang yang mengalami keterbatasan fisik, intelektual, mental, dan/ atau sensorik dalam jangka waktu lama yang dalam berinteraksi dengan lingkungan dapat mengalami hambatan dan kesulitan untuk 
Citra Gaffara Taqwarahmah, Bagus Riyono, Diana Setiyawati -- Peran Karang Taruna Dalam Pemberdayaan Penyandang Disabilitas Di Desa Karangpatihan, Kabupaten Ponorogo Dan Implikasinya Terhadap Ketahanan

Ekonomi Keluarga

berpartisipasi secara penuh dan efektif dengan warga negara lainnya berdasarkan kesamaan hak."

Desa Karangpatih memiliki fenomena terkait dengan warga desanya yang banyak mengalami disabilitas. Hasil penelitian yang dilakukan oleh Balai Besar Teknologi Kesehatan Lingkungan (BBTKL) Surabaya menunjukkan hasil uji laboratorium terhadap contoh air tanah ternyata seluruh sampel tidak terdeteksi adanya kadar yodium serta kondisi alam memiliki faktor resiko yang potensial mengandung logam berat $\mathrm{Cd}$ (Cadnium), $\mathrm{Hg}$ (Mercurry), Co (Kobbalt) dan PB (Timah Hitam) yang hal tersebut dapat menggangu absorbs yodium ke dalam tubuh (Badan Penelitian dan Pengembangan Kesehatan Kementerian Kesehatan RI, 2011).

Hasil tersebut juga diperjelas kembali oleh kepala Puskesmas Kecamatan Balong, bahwa:

"Dulu itu pernah ada kebiasaan untuk menanam baterai yang diyakini untuk menambah kesuburan, tapi justru dengan begitu malah dia kontra terhadap kandungan yodium sehingga yodiumnya hilang. Di sana pernah diteliti kandungan yodium di dalam air tanah ternyata nol. Sehingga apa yang dikonsumsi warga di sana melalui air dan tumbuhan tidak mengandung yodium" (wawancara Hermansyah, Kepala Puskesmas Kecamatan Balong, Tanggal 4 Febuari 2016).

Melihat kondisi demikian menimbulkan kesadaran pada pemuda karang untuk membuat sebuah kegiatan pemberdayaan yang dapat mendorong kemandirian penyandang disabilitas yang nantinya akan berdampak pada pola kehidupan dan kesejahteraan penyandang disabilitas. Pemberdayaan merupakan rangkaian proses untuk menghilangkan ketidakberdayaan yang dari kelompok minoritas.

Aplikasi dari pemberdayaan sebagai upaya mengurangi ketidakberdayaan penyandang disabilitas di Desa Karangpatihan merupakan sebuah hal yang tepat sasaran. Kegiatan yang dipilih sebagai program pemberdayaan adalah pembudidayaan ikan lele dan kerajinan keset. Pemilihan kegiatan pemberdayaan budidaya ikan dan pembuatan kerajinan keset didasarkan atas 3 (tiga) hal.

Pertama, bantuan yang saat itu datang sebagian besar merupakan bantuan yang bersifat konsumtif sehingga membentuk kebiasaan warga penyandang disabilitas menggantungkan hidup pada pemberian sumbangan.

Kedua, dipilihnya ikan lele karena cenderung mudah dan masa panen yang singkat antara 2,5-3 bulan. Adapun asumsi dari biaya pengeluran budidaya ikan lele dapat diihat pada tebel 1 di bawah ini.

Tabel 1

Biaya Variabel Pengeluaran Satu Periode Panen

\begin{tabular}{|c|c|c|}
\hline No & Kebutuhan & Jumlah \\
\hline 1. & $\begin{array}{l}\text { Benih ikan lele (ukuran 7-8cm) } 1000 \mathrm{x} \\
\text { Rp } 150\end{array}$ & Rp. 150.000 \\
\hline 2. & Pakan 100 kg x Rp. 6.000 & Rp. 600.000 \\
\hline 3. & Vitamin & Rp. 50.000 \\
\hline & Jumlah & Rp. 800.000 \\
\hline
\end{tabular}

Sumber : Data olahan peneliti

Berdasarkan biaya variabel pengeluaran pada tabel 1 di atas, asumsi keuntungan yang diperoleh dengan pemberian tingkat kegagalan sebanyak $30 \%$, dengan harga jual per $1 \mathrm{~kg}$ daging ikan lele sebesar Rp 16.000 dan pemasukan yang diperoleh 70 $\mathrm{kg}$ maka diperoleh hitungan sebagai berikut : Rp. 1.120.000 (Pemasukan) - Rp. 800.000 $($ Pengeluaran biaya variabel $)=$ Rp. 320.000 (Laba) 
Ketiga, pelatihan pembuatan kerajinan keset sebagai upaya untuk melatih penyandang disabilitas agar dapat produktif dan memiliki ketrampilan. Dalam sehari setiap warga penyandang disabilitas mampu membuat 1 -2 buah keset dengan harga jual Rp 15.000 perkeset. Dari harga jual Rp 15.000 ini, Rp 7.500 dialokasikan untuk biaya produksi dan Rp 7.500 untuk upah pembuat.

\section{Peran Karang Taruna Dalam Pemberdayaan Penyandang Disabilitas}

Membangun karakter pemuda yang dilakukan organisasi kepemudaan merupakan salah satu peran yang dilakukan oleh organisasi kepemudaan. Undang-Undang Nomor 20 Tahun 2009 tentang Kepemudaan, pada Pasal 43 menjelaskan bahwa organisasi kepemudaan harus memiliki keanggotaan, kepengurusan, tata laksana kesekretariatan dan keuangan, serta anggaran dasar dan anggaran rumah tangga. Pada Pasal 1 ayat (1) juga menjelaskan bahwa pemuda adalah warga negara Indonesia yang memasuki periode penting pertumbuhan dan perkembangan yang berusia 16 (enam belas) sampai 30 (tiga puluh) tahun. Pembangunan karakter pemuda melalui organisasi pada dasarnya sangat efektif, apabila seluruh rangkaian kegiatannya dapat berjalan dengan maksimal (Widiatmaka, 2016).

Keberadaan warga penyandang disabilitas harus menjadi perhatian bagi pemerintah khususnya pemerintah desa dan masyarakat agar mampu mengembangkan potensi yang ada pada penyandang disabilitas. Karang taruna sebagai representatisi pemuda Desa Karangpatihan telah mampu mendorong partisipasi seluruh elemen masyarakat di Desa Karangpatih untuk konsen dalam membantu penyandang disabilitas. Karang Taruna Desa Karangpatihan dalam hal ini mampu membangun kesadaran masyarakat untuk berperan dalam kegiatan pemberdayaan.

Kesadaran dari masyarakat yang timbul dari kegiatan ini yaitu perubahan stigma negatif yang disandarkan kepada penyandang disabilitas yang menyebutkan bahwa penyandang disabilitas hanya sebagai beban sosial yang tidak mampu berdaya. Di samping perubahan stigma, perubahan pada sektor ekonomi juga dirasakan oleh penyandang disabilitas di mana terdapat penghasilan dan kesempatan kerja.

\section{Keberdayaan Penyandang Disabilitas}

Keberadaan penyandang disabilitas seringkali dianggap beban sosial dan ekonomi bagi keluarga maupun lingkungan. Dari sini membentuk sebuah kontruksi sosial di mana menempatkan penyandang disabilitas sebagai aib. Oleh sebab itu, keberdayaan di sini diartikan sebagai keterlibatan dari penyandang disabilitas dalam menjalankan sebuah kegiatan yang mampu beraktivitas di lingkungan sebagaimana masyarakat yang lain. Upaya untuk mampu merubah stigma masyarakat yang menempatkan penyandang disabilitas sebagai beban semata mampu memberikan kesempatan untuk ikut andil dalam perubahan pada diri sendiri dan lingkungan.

Penelitian ini menunjukkan bahwa terjadi keberdayaan penyandang disabilitas dengan timbulnya kemandirian penyandang disabilitas. Dalam hal ini kemandirian yang dimaksud bukan hanya sekedar pada pencapaian peningkatan pendapatan semata, kemandirian di sini diartikan kemandirian pada aktivitas penyandang disabilitas itu sendiri. Kemauan untuk merubah kondisi dan keinginan untuk melakukan aktivitas membuat penyandang disabilitas memiliki 
Citra Gaffara Taqwarahmah, Bagus Riyono, Diana Setiyawati -- Peran Karang Taruna Dalam Pemberdayaan Penyandang Disabilitas Di Desa Karangpatihan, Kabupaten Ponorogo Dan Implikasinya Terhadap Ketahanan

Ekonomi Keluarga

kesempatan untuk melakukan kegiatan yang dapat menciptakan ketrampilan dan kesempatan kerja sehingga mampu berperan aktif dalam peningkatan ekonomi keluarga.

Melalui kegiatan pemberdayaan, penyandang disabilitas memiliki penghasilan per hari dengan kegiatan kerajinan keset dan penghasilan per bulan melalui pembudidayaan ikan lele. Program tersebut merupakan upaya yang dilakukan untuk meningkatkan taraf hidup penyandang disabilitas. Dengan berbekal ketrampilan tersebut diharapkan penyandang disabilitas dapat mengurangi beban keluarga dan mampu membuka akses terhadap hak kesejahteraan sosial.

Pada penelitian ini diperoleh data lapangan terkait pendapatan yang dihasilkan para penyandang disabilitas, sebagaimana ditunjukkan pada tabel 2 dan tabel 3 .

Berdasar kedua tabel tersebut dapat ditunjukkan bahwa terdapat peningkatan pendapatan yang berasal dari kegiatan pemberdayaan. Adanya perbedaan pendapatan dari setiap peserta pemberdayaan disebabkan oleh tingkat keuletan antara penyandang disabilitas yang berbeda-beda, dan faktor fisik antara individu. Adapun pada peningkatan pendapatan penyandang disabilitas setelah mengikuti kegiatan pemberdayaan mengalami peningkatan yang tidak signifikan namun dengan adanya pemberdayaan ini penyandang disabilitas yang sebelumnya tidak memiliki pendapatan kini mampu membantu perekonomian keluarga. Peningkatan

Tabel 2

Pendapatan Disabilitas Sebelum Kegiatan Pemberdayaan

\begin{tabular}{|c|c|c|c|c|c|c|}
\hline No & Kepala Keluarga & $\begin{array}{c}\text { Jumlah } \\
\text { keluarga }\end{array}$ & $\begin{array}{c}\text { Pendapatan Informan } \\
\text { Peb Bulan } \\
\text { (Rp) }\end{array}$ & $\begin{array}{l}\text { Pendapatan Anggota } \\
\text { Keluarga lain Per bulan } \\
(\mathrm{Rp})\end{array}$ & $\begin{array}{l}\text { Total pendapatan } \\
\text { Per bulan } \\
\text { (Rp) }\end{array}$ & $\begin{array}{c}\text { Pendapatan Per } \\
\text { hari } \\
(\mathrm{Rp})\end{array}$ \\
\hline 1. & Mesidi & 4 & 200.000 & 120.000 & 320.000 & 10.600 \\
\hline 2. & Wandi & 3 & 200.000 & - & 200.000 & 6.600 \\
\hline 3. & Khoirin & 4 & 200.000 & 80.000 & 280.000 & 9.400 \\
\hline 4. & Parmi & 3 & 200.000 & - & 200.000 & 6.600 \\
\hline 5. & Sipon & 3 & 250.000 & - & 250.000 & 8.400 \\
\hline 6. & Boini & 4 & - & 200.000 & 200.000 & 6.600 \\
\hline 7. & Lestari & 3 & - & 250.000 & 250.000 & 8.4000 \\
\hline 8. & Sarmi A & 2 & - & 100.000 & 100.000 & 3500 \\
\hline 9. & Suratun & 5 & 200.000 & 450.000 & 650.000 & 21.600 \\
\hline 10. & Tukirin & 5 & - & 650.000 & 650.000 & 21.600 \\
\hline 11. & Sibo & 3 & - & 250.0001 & 250.000 & 8.400 \\
\hline 12. & Sarmi B & 6 & 250.000 & 1.200 .000 & 1.450 .000 & 48.400 \\
\hline 13 & Jamun & 3 & - & 250.000 & 250.000 & 8.400 \\
\hline 14. & Ndari & 4 & - & 300.000 & 300.000 & 10.000 \\
\hline 15. & Boniyem & 4 & - & 450.000 & 450.000 & 15.000 \\
\hline 16. & Mesinah Semok & 3 & - & 200.000 & 200.000 & 6.600 \\
\hline 17 & Sarmini Mentil & 3 & - & 500.000 & 500.000 & 16.000 \\
\hline 18. & Cempluk & 5 & - & 600.000 & 600.000 & 20.000 \\
\hline
\end{tabular}

Sumber : Data olahan peneliti 
Tabel 3

Pendapatan Penyandang Disabilitas Setelah Ada Pemberdayaan

\begin{tabular}{|c|c|c|c|c|c|c|c|}
\hline \multirow[b]{2}{*}{ No } & \multirow[b]{2}{*}{ Nama } & \multicolumn{3}{|c|}{ Pendapatan Per bulan } & \multirow{2}{*}{$\begin{array}{c}\text { Pendapatan } \\
\text { Anggota Keluarga } \\
\text { lain per bulan }\end{array}$} & \multirow{2}{*}{$\begin{array}{c}\text { Total } \\
\text { pendapatan } \\
\text { perbulan }\end{array}$} & \multirow{2}{*}{$\begin{array}{c}\text { Pendapatan } \\
\text { Per hari }\end{array}$} \\
\hline & & Utama & P.ikan Lele & $\begin{array}{c}\text { P. Kerajinan } \\
\text { Keset }\end{array}$ & & & \\
\hline 1. & Mesidi & 320.000 & 110.000 & 60.000 & 120.000 & 610.000 & 21.000 \\
\hline 2. & Wandi & 200.000 & 107.000 & 52.000 & - & 359.000 & 11.9600 \\
\hline 3. & Khoirin & 280.000 & - & 120.000 & 80.000 & 480.000 & 16.000 \\
\hline 4. & Parmi & 200.000 & 110.000 & 120.000 & - & 430.000 & 14.400 \\
\hline 5. & Sipon & 250.000 & 110.000 & 120.000 & - & 470.000 & 15.600 \\
\hline 6 & Boini & - & - & 120.000 & 200.000 & 320.000 & 10.600 \\
\hline 7. & Lestari & - & - & 60.000 & 250.000 & 310.000 & 10.300 \\
\hline 8. & Sarmi A & - & 120.000 & 60.000 & 100.000 & 280.000 & 9.400 \\
\hline 9. & Suratun & 200.000 & 110.000 & 120.000 & 650.000 & 1.080 .000 & 36.000 \\
\hline 10. & Tukirin & - & 110.000 & 30.000 & 650.000 & 790.000 & 26.400 \\
\hline 11. & Sibo & - & 120.000 & 120.000 & 250.000 & 490.000 & 16.400 \\
\hline 12. & Sarmi B & 250.000 & - & 120.000 & 1.450 .000 & 1.820 .000 & 60.000 \\
\hline 13. & Jamun & - & 110.000 & - & 250.000 & 360.000 & 12.000 \\
\hline 14. & Ndari & - & 120.000 & 60.000 & 300.000 & 480.000 & 16.000 \\
\hline 15. & Boniyem & - & - & 120.000 & 450.000 & 570.000 & 19.000 \\
\hline 16. & Mesinah Semok & - & - & 60.000 & 200.000 & 260.000 & 8.6000 \\
\hline 17. & Sarmini Mentil & - & 110.000 & 60.000 & 500.000 & 670.000 & 22.400 \\
\hline 18. & Cempluk & - & - & 120.000 & 600.000 & 720.000 & 24.0000 \\
\hline
\end{tabular}

Sumber : Data olahan peneliti

pendapatan tidak menjamin bahwa keluarga telah menikmati kesejahteraan.

\section{Kendala Kegiatan Pemberdayaan Penyandang Disabilitas}

Pada hasil observasi yang diamati peneliti menunjukkan bahwa mayoritas dari penyandang disabilitas di Dusun Tanggungrejo masuk pada klasifikasi retradasi mental atau tuna grahita, di mana perkembangan pada mental dari tuna grahita mengalami keterlambatan. Salah satu pengaruh dalam keberdayaan sangat dipengaruhi oleh partisipasi aktor kegiatan dan sasaran kegiatan itu sendiri. Kendala yang cukup dirasakan adalah komunikasi, para penyandang disabilitas yang mengikuti program pemberdayaan memiliki masalah dengan komunikasi dan kemampuan untuk berfikir.
Hal tersebut mengharuskan para pendamping kegiatan pemberdayaan untuk ikut memberikan contoh langsung dalam pelatihan kegiatan pemberdayaan. Dari penuturan informan dijelaskan kendala yang dirasakan, yaitu :

"Kesulitan paling terlihat adalah masalah bahasa. Terkadang kita harus mengulangulang omongan kita. Meski sudah diulang omongan, mereka masih tetap melakukan kesalahan. Jadi kalau mengajak mereka ngomong itu harus menggunakan penekanan dan bahasa tubuh yang jelas. " (wawancara Bapak Samuji, Tanggal 6 Febuari 2016)

Kesulitan dalam berkomunikasi menyebabkan transfer ilmu tidak berjalan maksimal. Dalam menjalankan kegiatan masih memiliki hambatan yang dikarenakan keterbatasan warga penyandang disabilitas 
Citra Gaffara Taqwarahmah, Bagus Riyono, Diana Setiyawati -- Peran Karang Taruna Dalam Pemberdayaan Penyandang Disabilitas Di Desa Karangpatihan, Kabupaten Ponorogo Dan Implikasinya Terhadap Ketahanan

Ekonomi Keluarga

yang sulit untuk diarahkan. Kesulitan ini menyebabkan hasil yang tidak maksimal yang tergantung suasana hati warga penyandang disabilitas yang diberdayakan.

Di samping faktor fisik, sikap negatif kepada penyandang disabilitas masih terlihat di sebagian masyarakat. Keraguan masyarakat dan keluarga pada kemampuan penyandang disabilitas masih terlihat, di mana ketika melakukan wawancara dan observasi banyak dari anggota keluarga yang menempatkan penyandang disabilitas sebagai orang cacat dan tidak bisa melakukan aktivitas yang berat. Pemahaman ini yang kemudian berdampak pada hak hidup penyandang disabilitas. Sikap negatif dari lingkungan menjadikan penyandang disabilitas serta keluarganya menjadi pasrah pada keadaan yang dialami yang berpengaruh terhadap rasa nyaman terhadap keadaannya. Kondisi ini hendaklah mendapatkan sosialisasi dan pengarahan lebih lanjut oleh pihak terkait, sehingga meskipun dengan keterbatasan penyandang disabilitas masih mampu mengembangkan kemampuan yang ada pada diri sendiri dan lingkungan.

\section{Implikasinya Terhadap Ketahanan Ekonomi Keluarga}

Ketahanan ekonomi adalah sebuah kondisi kehidupan perekonomian bangsa. Salah satu bagian dari ketahanan ekonomi adalah ketahanan ekonomi keluarga, karena pada dasarnya ekonomi merupakan bagian yang menopang kebutuhan hidup keluarga. Sebagian besar kebutuhan hidup yang harus dihadapi oleh keluarga setiap hari adalah kebutuhan ekonomi, seperti pendapatan yang pada akhirnya digunakan untuk memenuhi kebutuhan hidup keluarga. Ketahanan ekonomi keluarga dapat dipenuhi bila keluarga tersebut memiliki pekerjaan atau usaha dengan penghasilan yang cukup untuk memenuhi kebutuhan ekonomi keluarga. Ketahanan ekonomi keluarga mencakup ketahanan pangan, kesehatan, pendidikan dan kebutuhan lainnya yang bersifat sekunder dan tersier.

Menurut penelitian Center for International Forestry Research (2004) setidaknya keluarga yang mampu memenuhi kebutuhan dasar meliputi makanan yang memenuhi standar gizi, pakaian yang layak, tempat tinggal yang layak, pendidikan dan pelayanan kesehatan yang memadai merupakan indikator dari sebuah keluarga sejahtera. Indikator yang digunakan dalam penelitian ini untuk mengetahui implikasi ketahanan ekonomi keluarga penyandang disabilitas pada peningkatan kesejahteraan melalui pendapatan pembudidayaan ikan lele dan kerajinan keset yang mengacu pada pemenuhan kebutuhan fisik (Physiological need) yang selanjutnya dianalisis dengan pendekatan kemiskinan World Bank.

Menurut World Bank (2006) indikator penghasilan minimum US $\$ 1$ atau setara dengan Rp.13.000 menjadi ukuran dalam menghitung kemiskinan sebuah keluarga, yaitu (1) kategori sangat miskin yang dapat dilihat dari indikator pendapatan per kapita per hari sebesar kurang dari US \$1 (2) kategori miskin dilihat dari indikator pendapatan per kapita per hari antara US \$1 hingga US \$2, (3) dan kategori tidak miskin dilihat dari indikator pendapatan per kapita per hari sebesar lebih dari US \$2.

Pada dasarnya kemiskinan dikaitkan dengan perkiraan tingkat pendapatan dan kebutuhan di mana perkiraan kebutuhan tersebut hanya dibatasi pada kebutuhan pokok sebagai kebutuhan minimum. Namun apabila pendapatan tersebut tidak mampu memenuhi kebutuhan minimum maka seseorang dapat 
Tabel 4.

Pendapatan Penyandang Disabilitas Yang Telah Dikonversikan Dengan Standar World Bank

\begin{tabular}{|c|c|c|c|c|c|}
\hline \multirow[b]{2}{*}{ No } & \multirow[b]{2}{*}{ Nama } & \multirow[b]{2}{*}{ Pendapatan Per Hari } & \multicolumn{3}{|c|}{ Standart World Bank } \\
\hline & & & $\begin{array}{c}\text { Sangat Miskin } \\
(<\mathrm{US} \$ 1)\end{array}$ & $\begin{array}{c}\text { Miskin } \\
\text { (US \$1- US \$2) }\end{array}$ & $\begin{array}{c}\text { Tidak Miskin } \\
(>\text { US \$2) }\end{array}$ \\
\hline 1. & Mesidi & 21.000 & & $\mathrm{M}$ & \\
\hline 2. & Wandi & 11.9600 & SM & & \\
\hline 3. & Khoirin & 16.000 & SM & & \\
\hline 4. & Parmi & 14.400 & & M & \\
\hline 5. & Sipon & 15.600 & & M & \\
\hline 6 & Boini & 10.600 & SM & & \\
\hline 7. & Lestari & 10.300 & SM & & \\
\hline 8. & Sarmi A & 9.400 & SM & & \\
\hline 9. & Suratun & 36.000 & & & $\mathrm{TM}$ \\
\hline 10. & Tukirin & 26.400 & & M & \\
\hline 11. & Sibo & 16.400 & & M & \\
\hline 12. & Sarmi B & 60.000 & & & $\mathrm{TM}$ \\
\hline 13. & Jamun & 12.000 & SM & & \\
\hline 14. & Ndari & 16.000 & & M & \\
\hline 15. & Boniyem & 19.000 & & M & \\
\hline 16. & Mesinah Semok & 8.6000 & SM & & \\
\hline 17. & Sarmini Mentil & 22.400 & & M & \\
\hline 18. & Cempluk & 24.0000 & & M & \\
\hline
\end{tabular}

Sumber : Data olahan peneliti

dikatakan miskin (Arsyad, 2004). Namun demikian pendapatan bukan merupakan satu-satunya indikator kemakmuran karena pendapatan per kapita tidak selalu menjamin sebuah keluarga telah makmur. Pendapatan hanya digunakan sebagai gambaran umum dari kesejahteraan karena inti permasalahan pada kemiskinan adalah batasan-batasan tentang kesejahteraan. Adapun hasil yang diperoleh ditunjukkan pada tabel 4 .

Kondisi ekonomi penyandang disabilitas setelah pemberdayaan dapat diketahui $40 \%$ penyandang disabilitas masuk pada kategori sangat miskin dan 50\% yang lain merupakan keluarga miskin. Gambaran yang terlihat dari pendapatan penyandang disabilitas melalui kegiatan pemberdayaan masih menempatkan mereka pada garis kemiskinan di mana sulit untuk memenuhi kebutuhan dasar non makan. Kemiskinan yang dialami oleh penyandang disabilitas maupun keluarga dari penyandang disabilitas bersifat alamiah dengan didorong kondisi lingkungan desa mereka. Kesempatan mereka untuk keluar dari belenggu kemiskinanpun sangat sulit. World Bank (2006) sendiri memberikan definisi tentang kemiskinan yaitu kehilangan kesejahteraan (deprivation of well being), sedangkan inti permasalahan pada kemiskinan adalah batasan-batasan tentang kesejahteraan itu sendiri.

Penelitian ini menunjukkan bahwa kegiatan pemberdayaan memberikan pengaruh terhadap peningkatan pendapatan penyandang disabilitas. Namun demikinan ketahanan ekonomi keluarga disabilitas dalam rangka peningkatan kesejahteraan tergolong sangat rendah, yang ditunjukkan dari 90\% penyandang disabilitas masuk dalam kondisi miskin dan sangat miskin. Kemampuan ekonomi keluarga penyandang disabilitas untuk memenuhi kebutuhan sehari-hari 
Citra Gaffara Taqwarahmah, Bagus Riyono, Diana Setiyawati -- Peran Karang Taruna Dalam Pemberdayaan Penyandang Disabilitas Di Desa Karangpatihan, Kabupaten Ponorogo Dan Implikasinya Terhadap Ketahanan

Ekonomi Keluarga

mengalami hambatan dan gangguan yang akan berimbas pada munculnya ancaman yang menjamin kelangsungan perekonomian dan kehidupan keluarga.

\section{SIMPULAN}

Berdasarkan uraian di atas dapat ditarik simpulan sebagai berikut.

Pertama, peran yang telah dilakukan oleh Karang Taruna berkaitan dalam pemberdayaan penyandang disabilitas yakni: (1) Peran Karang Taruna sebagai fasilitator dan kordinator.Karang Taruna dalam kegiatan pemberdayaan berperan sebagai tenaga profesional atau tenaga ahli yang bertugas memfasilitasi sekaligus mendamping pada setiap proses pemberdayaan. (2) Peran Karang Taruna sebagai agen perubahan (Agent of Change). Kegiatan yang selama ini telah dijalankan Karang Taruna Desa Karangpatihan mampu mengubah kebiasaan yang ada dalam masyarakat yaitu, terbukanya kesempatan pemuda untuk menyampaikan gagasan kepada forum desa, pemuda menjadi pengagas dibangunnya kegiatan-kegiatan pemberdayaan bagi warga disabilitas dan pemuda dapat mendorong warga untuk ikut serta dalam kegiatan pemberdayaan.

Kedua, kegiatan pemberdayaan penyandang disabilitas Dusun Tanggungrejo memberi kontribusi dalam peningkatan pendapatan keluarga. Dengan adanya pemberdayaan, penyandang disabilitas yang awalnya tidak memiliki kesempatan kerja mampu diberdayakan sehingga memiliki penghasilan dari kegiatan tersebut. Peningkatan pendapatan penyandang disabilitas berpengaruh terhadap kemandirian ekonomi yang mengurangi ketergantungan terhadap bantuan dan pemberian orang lain. Namun di sisi lain, kemandirian ekonomi yang tercipta dari kegiatan pemberdayaan belum mampu berpengaruh terhadap ketahanan ekonomi keluarga. Pendapatan penyandang disabilitas yang berasal dari luar pemberdayaan maupun dari pemberdayaan ketika dikonversikan dengan standar kemiskinan World Bank masih jauh dari sejahtera. Adapun kontribusi dari penyandang disabilitas yang belum berkeluarga tidak mampu menopang kehidupannya sendiri. Hal ini mengakibatkan kondisi keluarga penyandang disabilitas masih rentan terhadap ancaman, gangguan dan hambatan yang berasal dari luar maupun dalam yang diakibatkan ketidakmampuan untuk memenuhi kebutuhan sehari-hari.

\section{DAFTAR PUSTAKA}

Arsyad, Lincoln, 2004 . Ekonomi Pembangunan, Edisi Ke-empat, STIE YKPN

Badan Penelitian dan $\mathrm{P}$ e $\mathrm{n} g$ e $\mathrm{m}$ b a $\mathrm{n} \mathrm{g}$ a $\mathrm{n}$ Kesehatan, Kementrian Kesehatan RI, 2011, Jurnal Penelitian, Studi Pola Budaya Teknologi Pangan Masyarakat Keluarga Balita Desa Karangpatihan, Kecamatan Balong, Kabupaten Ponorogo, Provinsi Jawa Timur.

Departemen Pertahanan RI, 2008, Buku Putih Pertahanan Indonesia, Jakarta, Departemen Pertahanan Republik Indonesia.

Huda, Achmad Nur, 2015, Tesis UGM, Kepemimpinan Kepala Desa Dalam Menigkatkan Sumber Daya Manusia Di Desa Karangpatihan (Studi Kasus Pada Masyarakat Miskin dan Penderita Retradasi Mental Di Desa Karangpatihan, Kecamatan Balong, Kabupaten Ponorogo)

Oktavianti, Fanny Kartika, 2014, Jurnal Ketahanan Nasional UGM, Pendapatan Pembudidayaan Ikan Anggota Kelompok 
Wirausaha Pemuda dan Implikasinya Terhadap Ketahanan Ekonomi Keluarga (Studi Di Kelompok Wisrausaha Pemuda Kota Palangkaraya Provinsi Kalimantan Tengah)

Shofa, Abd Mu'id Aris, 2016, Jurnal Ketahanan Nasional UGM, Peran Pemuda Dalam Pendampingan Mahasiswa dan Implikasinya Terhadap Ketahanan Pribadi (Studi di Pusat Layanan Difabel (PLD) UIN Sunan Kalijaga Yogyakarta.

Sumaryadi, Nyoman, 2005. Efektifitas Implementasi Kebijakan Otonomi Daerah. Jakarta : Citra Utama

Sutoso, Eko. 2002. Jurnal: Pemberdayaan Masyarakat Desa, Materi Diklat Pemberdayaan Masyarakat Desa, Yang Diselenggarakan Badan Diklat Propinsi Kaltim, Samarinda, Desember 2002.

Widiatmaka, Pipit, 2016, Jurnal Ketahanan Nasional UGM, Peran Organisasi Kepemudaan Dalam Membangun Karakter Pemuda dan Implikasinya Terhadap Ketahana Pribadi Pemuda (Studi Pada Pemimpin Cabang Gerakan Pemuda Ansor di Kabupaten Sukoharjo Provinsi Jawa Tengah)

World Bank, 2006. Making The New Indonesia Work Of the Poor, Jakarta
Yusuf, Ilma Fatimah, 2016, Jurnal Ketahanan Nasional UGM, Peran Pemuda Dalam Pengembangan Eduwisata Energi Terbarukan Dan Implikasinya Terhadap Ketahanan Keluarga.

Zulkarnain, Muhammad Iskandar, 2015, Jurnal Ketahanan Nasional UGM, Peran Balai Pemuda dan Olahraga Yogyakarta Dalam Upaya Pengembangan Kewirausahaan Untuk Mendukung Ketahanan Ekonomi Keluarga (Studi Tentang Persepsi Peserta Kegiatan Pelatihan Ketrampilan BPO DIY)

Peraturan Perundangan

Undang-Undang Nomor 40 tahun 2009 tentang Kepemudaan.

Peraturan Menteri Sosial No. 77/HUK/2010 Tentang Karang Taruna

Undang-Undang Nomor 8 Tahun 2016 Tentang Penyandang Disabilitas

\section{Internet}

(www.kemenpppa.go.id diakses pada tanggal 4 April 2016

\section{Wawancara}

1. Bapak Hermansyah

2. Bapak Samuji 